\title{
THE INFLUENCE OF PRINCIPALS' TECHNOLOGY LEADERSHIP AND PROFESSIONAL DEVELOPMENT ON TEACHERS' TECHNOLOGY INTEGRATION IN SECONDARY SCHOOLS
}

\author{
${ }^{1}$ Raamani Thannimalai \& ${ }^{2}$ Arumugam Raman \\ School of Education and Modern Languages \\ Universiti Utara Malaysia, Malaysia
}

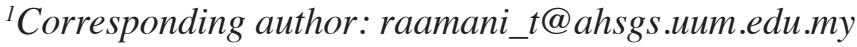

Received: 12 February 2018

Accepted:

\section{ABSTRACT}

Purpose - The aim of this study was to identify the level of Principals' Technology Leadership and its five constructs namely Visionary Leadership, Digital Age Learning Culture, Excellence in Professional Practice, Systemic Improvement, and Digital Citizenship in schools. In addition, the relationship between Principals' Technology Leadership and Teachers' Technology Integration was measured. Besides that, the effect of Professional Development as a moderator of the mentioned relationship was also investigated.

Methodology - Systematic random sampling was carried out to select 90 principals and 645 teachers from National Secondary Schools in Kedah, Malaysia in this cross-sectional survey. The Principals Technology Leadership Assessment (PTLA) which is based on National Education Technology Standards -Administrator, NETS-A (2009), and Survey of Technology Experiences' were administered to principals, while the Learning with ICT: Measuring ICT Use in the Curriculum Instrument was administered to the teachers.

Findings - The study showed that there was a significant relationship between Principals' Technology Leadership and Teachers' Technology Integration. Furthermore, Professional 
Development had a significant effect on the relationship between the two variables.

Significance - Professional development emphasising ICT must be carried out for school principals so that they can become technology leaders and motivate teachers to integrate technology in the classroom to prepare students as skilled workers for Industrial Revolution 4.0.

Keywords: Professional development, Teachers' technological integration, Principals' technology leadership.

\section{INTRODUCTION}

Education systems worldwide have to brace for the imminent Fourth Industrial Revolution as the job market will be largely prompted by the advancement of the digital economy, robotics, artificial intelligences and automation technology. Nevertheless, certain human related abilities remain relevant, making them essential virtues of the human capital sought by the upcoming industrial era. The impending challenge thus requires all school principals and teachers to adopt an open mind on the changes and advances brought by rapid development in technology. In the Malaysian context, school leaders, precisely principals and teachers have to transform themselves as the Industrial Revolution 4.0 is pushing for the current education system to be revamped in line with the government's new policy, namely the Malaysia Education Blueprint 2013-2025 (Ministry of Education, 2013). Malaysian school leaders and teachers should be prepared to take on the challenge by equipping themselves with the latest Information and Communication Technology (ICT) skills. Principals are required to act as technology leaders and teachers as facilitators, to provide the skills and knowledge for $21^{\text {st }}$ century education (Roblyer \& Doering, 2014). A principal's responsibility is becoming even more challenging as schools need not only to produce skilled and creative workforce to meet the demands of the Digital Economy but also reengineer the way students think in a constantly transforming era. Therefore, principals should possess enough ICT skills and knowledge to guide, motivate and spearhead initiatives for teachers to integrate technology in the classroom, in line with the seventh shift of the Malaysia Education Blueprint (2013-2025) 
(MOE, 2013) which has now entered the second wave (2016-2020). In addition, there were earlier government policies, such as the Interim Strategic Plan (2011-2020) (MOE, 2012), emphasising that ICT needs to be integrated into the teaching and learning processes, management and administration of schools.

For the past decade, school principals in Malaysia had to choose their own training and professional development courses and were self-assessed online using a leadership model formulated by Institut Aminudin Baki, called the Leadership Competency School (KOMPAS) (MOE, 2013). However, previous studies have shown that principals could not identify the appropriate professional development needed to become effective principals (Machado \& Chung, 2015). Further studies should be conducted to identify if technology leadership is one of the areas that should be emphasised in the professional development of principals, so that they are qualified to inspire teachers and students of the $\mathrm{Y}$ and $\mathrm{Z}$ generations, respectively.

Many studies related to the use of technology in secondary schools (Fullan, 2001; Senge, 1990; Michael, 1998; Johnston \& Cooley, 2001; Hamzah, Juraime, Hamid, Nordin \& Attan, 2014) agree that principals play a key role in the use of ICT in the classroom. Additionally, studies such as by Richardson and McLeod (2011), Wang (2010), Badri, Alnuaimi, Mohaidat, Yang, and Al Rashedi (2016), and Evers, Van der Heijden, and Kreijns (2016) suggest that professional development should be further examined.

Previous studies pertaining to principals' leadership were more focused on primary factors such as technology literacy (Chang, 2012), technology leadership in High-Performance Schools or Sekolah Bestari (Hamzah et al., 2014), the impact and role of school leaders (Anderson \& Dexter, 2005; Fisher \& Waller, 2013), leadership style (Tan, 2010), distributive leadership (Dexter, 2008) and teacher's ICT competence (Leong, Chua, \& Sathiamoorthy, 2016). However, Wang (2010); Richardson and McLeod (2011); Fisher and Waller (2013); Dunham (2012), and Sincar (2013) suggested that professional development components should be investigated as research variables. Studies on principals' leadership and their professional development needs have not been widely researched in western countries (GreyBowen, 2010) and not many studies have been done on these two variables, more so in the Malaysian context. 
A study by Bredeson (2000) clearly stated the role of principals in professional development while Bizzell (2011) found that most professional development courses attended by principals were not continuous and rarely uses digital technology. In addition, all surveyed principals said that they needed training in the use of ICT in education and administration. Furthermore, Grissom and Harrington (2010) highlighted that although there is much literature on professional development for teachers, there is a lack of research on professional development for principals.

Over the last decade, studies on Technology Leadership only used the National Education Technology Standards - Administrator (NETS-A) standard as a whole to study the integration of technology (Alkrdem, 2014). Although there have been studies linking NETS-A (2009) with other variables such as receiving and using SMS by teachers (UTAUT2) (Leong, Chua, Sathiamoorthy \& Shafinaz, 2016), not many studies in Malaysia had investigated the relationship of the five constructs of NETS-A (2009) with Teachers' Technology Integration in secondary schools. In addition, most studies used the NETS-A (2002) and not the latest standard introduced by ISTE, which is the NETS-A (2009) (Hamzah et al., 2014; Chang, 2012; Hamzah, Nordin, Jusoff, Karim, \& Yusof, 2017; Machado \& Chung, 2015). Moreover, not many have studied the relationship and level of each of the five constructs in NETS-A (2009) with the use of ICT in the classroom (Leong et al., 2016). Therefore, this research studies this prevailing gap.

According to Anderson and Dexter (2005) and Dexter (2011), Technology Leadership represents all technology-related activities at school including organisational decisions, policies, and technology implementation. There are five constructs under Technology Leadership, namely Visionary Leadership, Digital Age Learning Culture, Excellence in Professional Practice, Systemic Improvement, and Digital Citizenship. In this study, all these constructs are measured using the Likert scale point (1-5).

The aim of this study was to identify the relationship between the five constructs of the National Education Technology StandardsAdministrator (2009), namely Visionary Leadership, Digital Age Learning Culture, Excellence in Professional Practice, Systemic Improvement, and Digital Citizenship, with Teachers' Technology Integration (International Society for Technology in Education ([ISTE], 2009). In addition, professional development was investigated 
as a moderator based on previous researcher recommendations (Creswell, 2014).

The operational definitions for the five Technology Leadership constructs are as follows:

\section{Visionary Leadership}

School principals inspire, lead development and implementation of a shared vision for integration of technology to promote excellence and support transformation in the organisation. As technology leaders, principals communicate technology infused strategic plans aligned with a shared vision (International Society for Technology in Education (ISTE, 2014).

\section{Digital Age Learning Culture}

School principals create, promote, and sustain dynamic, digital age learning cultures that provide a rigorous, relevant, and engaging education for all students. Principals ensure instructional innovation and provide learner-centred environments equipped with technology and learning resources (ISTE, 2014).

\section{Excellence in Professional Practice}

Educational administrators promote an environment of professional learning and innovation that empowers teachers to enhance student learning through technologies and digital resources. The also stay abreast with emerging trends with regards to the use of technology (ISTE, 2014).

\section{Systemic Improvement}

School principals provide digital age leadership and management to continuously improve their schools. This is done through the effective use of information and technology resources. Principals also have to ensure that the infrastructure supports the teaching and learning develpoment (ISTE, 2014).

School principals provide digital age leadership and management to continuously improve schools through the effective use of information and technology resources. Principals also maintain infrastructure to support teaching and learning (ISTE, 2014). 


\section{Digital Citizenship}

School principals model and facilitate understanding of social, ethical, and legal issues and responsibilities related to an evolving digital culture. In addition, principals ensure access to digital tools and resources to meet the needs of all learners (ISTE, 2014).

Technology Integration can be defined as a combination of technology resources (computer and specialised software), network-based communication systems, tools, and other infrastructure, and technologybased practices that have been integrated into daily routines and student activities in the classroom (U.S. Department of Education, 2005). Professional Development can be defined as processes that enhance attitudes, skills, and knowledge about the career, include training in services, coaching, and other activities (Guskey \& Sparks, 1996).

Leadership theories in the past century have found that technology leadership is not a separate theory, but a development of leadership theories (Papa, 2011). According to Chin (2010), technology leadership theory differs from traditional leadership theories because it does not focus on the leader's features or actions, but emphasises that leaders should develop, guide, manage, and apply technology in different organisational operations with the aim of improving the organisation's performance.

Although many studies have reported that principals' leadership has an impact on the integration of educational technology, which in turn has a positive impact on student achievement improvement (Greaves, Hayes, Wilson, Gielniak, \& Peterson, 2010), research on leadership of principals is lacking (Albion, 2006; Davies, 2010; Richardson, Bathon, Flora, \& Lewis, 2012). Therefore, this study was conducted to demonstrate that principal's leadership in school has a positive relationship with the integration of technology.

Principals who create school vision for effective technology integration and provide continuous professional development have been observed to be most effective in influencing teacher's integrating technology in the classroom (Kurland, Peretz, Hertz-Lazarowitz, 2010). This finding is in line with Chang (2012) who conducted a study of 1,000 principals in Taiwan and found that principal's leadership improved teacher's literacy and directly influenced teachers to integrate technology into teaching. This study also proposed that the role of principals should change from traditional school administrators to technology and curricula 
leaders (Chang, 2012). In addition, Peled, Kali and Dori (2011) suggested that the characteristics and support of principals can alter the behaviour of Science teachers as it enhances or reduces the use of technology in the classroom according to the support received from the principal.

The technology leadership model proposed by Anderson and Dexter (2005) has integrated technology leadership based on NETS-A (ISTE, 2002). NETS-A was introduced by the International Society for Technology in Education (ISTE, 2002) and it is a suggestion on the knowledge and skills that school leaders must possess to initiate and support the integration of effective technology in an educational environment. NETS-A consists of five constructs which are: Visionary Leadership, Digital Age Learning Culture, Excellence in Professional Practice, Systemic Improvement, and Digital Improvement (ISTE, 2009).

Technology leadership is based mainly on the model introduced by Anderson and Dexter (2005). Their empirical study and literature is the most extensive in the field of school technology leadership. According to Anderson and Dexter (2005), technology leadership comprises of all activities related to technology in school, including organisations' decisions, policies, and technology implementation. This model explains the two-way relationship between technology leadership and school infrastructure. The increase of internet usage, technology integration, and usage of technology tools by students would demand strong technology leadership.

The objectives of this research are as follows:

i. To measure Principal's Technology Leadership level in terms of NETS-A standards.

ii. To measure Teachers' Technology Integration in classrooms for educational purposes.

iii. To measure the relationship between Principal's Technology Leadership level and Teachers' Technology Integration for educational purposes.

iv. To assess the effect of professional development as a moderator on the relationship between the Principals' Technology Leadership level and Teachers' Technology Integration for educational purposes.

The proposed model for this study is as shown in Figure 1. The independent variables were Principals' Technology Leadership, 
the five constructs of Technology Leadership which are Visionary Leadership, Digital Age Learning Culture, Excellence in Professional Practice, Systemic Improvement, and Digital Citizenship. The dependent variables are Teacher's Technology Integration and Professional Development. These components are the moderating factors.

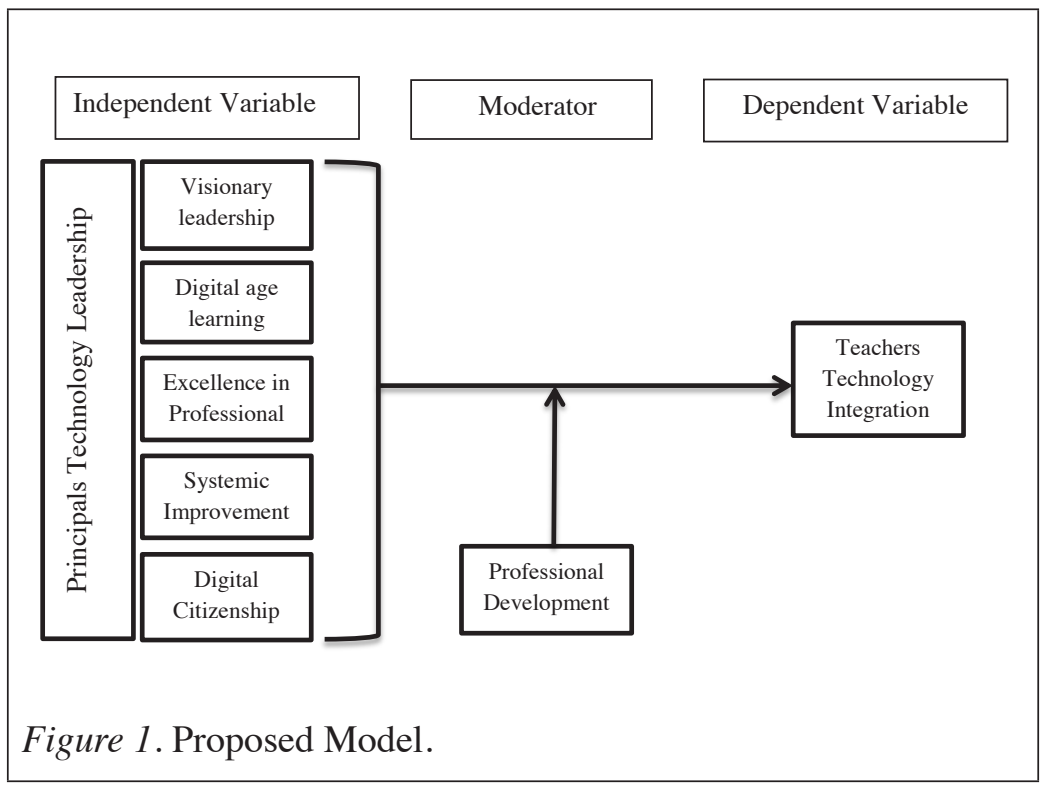

\section{METHODOLOGY}

This quantitative exploratory study used a cross sectional survey design, which is a non-experimental descriptive research method. The study was conducted on randomly selected samples with the aim of testing the technology leadership model and integrating technology into a large and normalised population.

\section{Participants}

The state of Kedah Malaysia, is divided into eight districts according to District Education Departments. The districts consist of Baling/ Sik, Kota Setar, Kuala Muda/Yan, Kubang Pasu, Kulim/Bandar Baru, Langkawi, Padang Terap, and Pendang, with a total of 158 government National Secondary Schools. 90 secondary school 
principals were randomly selected from these schools. A total of 645 teachers were also chosen from a population of 12,088 teachers in Kedah, based on Krejcie \& Morgan (1970). These teachers were chosen from the same schools as the principals so that the relationship between technology leadership of school principals and the integration of technology by the teachers could be measured.

\section{Sampling}

The sampling method used in this study was 'systematic random sampling' where each element in the population has the same chance to be selected as a sample (Latham, 2007). This technique uses a simple systematic formula of selecting each individual in the $\mathrm{n}$-th interval until the desired number of samples is achieved (MacNealy, 1999). The samples were chosen from a list of schools from the Kedah State Education Department (2017), which was arranged alphabetically and not according to school performance to avoid any biases (Noraini Idris, 2013).

\section{Instruments}

Two different questionnaires were used for principals and teachers. Principals were administered with the Principals Technology Leadership Assessment (PTLA), which is based on NETS-A by the International Society for Technology in Education (ISTE) (2009) to measure Technology Leadership. The PTLA consists of 20 questions with a five-point Likert scale from 'never' to 'always' and all respondents were asked to rate their technology leadership. It consists of five constructs, i) Visionary Leadership (Item KV1-KV2), ii) Digital Age Learning Culture (Item BP1-BP5), iii) Excellence in Professional Practice (KP1-KP4), iv) Systemic Improvement (Item PS1-PS5), and v) Digital Citizenship (KD1-KD4). The principal's instrument also included the Survey of Technology Experiences by Billheimer (2007) to measure the Professional Development needed by principals. The Survey of Technology Experiences is a categorical scale consisting of 18 statements which required a 'Yes' or 'No' response (Johnson \& Neyman, 1936).

Learning with ICT: Measuring ICTUse in the Curriculum Instrument, which was adopted and modified from Jamieson-Proctor, Watson, 
and Finger (2003), Jamieson-Proctor, Watson, Finger, and Grimbeek (2005), and Jamieson-Proctor, Finger, and Albion (2010), was used to measure Technology Integration of teachers. The questionnaire consisted of 20 questions with a five-point Likert scale from "never" to "always". Both instruments were translated using back-translation (Brislin, 1970) from English to Malay and back to English to see if the meaning was still the same. Both the questionnaires were validated by two experts in the field and were corrected according to their recommendations before they were used for the pilot study. The Cronbach's alpha of the pilot study showed that the questionnaires were valid and reliable (Nunnally, 1978).

\section{Data Analysis}

The analysis of the survey questionnaire was carried out using two statistical packages. The Statistical Package for the Social Sciences (SPSS) 23.0 was used for the descriptive analysis, and percentages, means, and standard deviations were used to describe the characteristics of the data. PROCESS (Hayes, 2012) was used for the inferential analyses of Technology Leadership (IV) and the five constructs of NETS-A (IV), Technology Integration (DV), and the Professional Development (Moderator). PROCESS (Hayes, 1995) was used to measure the relationship between Principals' Technology Leadership and Teachers' Technology Integration. One of the advantages of using PROCESS (Hayes, 1995) is that it can measure the effect of a moderator on the relationship between Principal's Technology Leadership and Technology Integration among teachers in the classroom. From the statistical analysis, a structural model was built.

\section{RESULT}

A pilot study was carried out in the neighbouring state of Perlis, to measure the reliability of both instruments. A total of 13 principals and 213 teachers of National Secondary Schools responded. The reliability of the overall PTLA was very high with Cronbach's alpha $\alpha=0.93$. The findings showed that the Digital Citizenship construct had the highest Cronbach's alpha of .89, followed by Excellence 
in Professional Practice ( $\alpha=0.87)$; Systemic Improvement $(\alpha=0.81)$; Digital Age Learning Culture $(\alpha=0.79)$, and the lowest was Visionary Leadership $(\alpha=0.62)$. Item-item correlation was analysed and item KV25 was deleted to obtain a better Cronbach's alpha coefficient $(\alpha=.72)$. The reliability of the Learning with ICT: Measuring ICT Use in the Curriculum Instrument was very high with Cronbach's alpha $(\alpha)=0.94$.

For the actual field research, 90 principals and 645 teachers responded. The response rate was $90 \%$ for principals and $89.5 \%$ for teachers respectively. Descriptive analysis was carried out using SPSS Version 23. Table 1 shows the profile of principals in this study.

Table 1

Profile of Principals

\begin{tabular}{lcc}
\hline \multicolumn{1}{c}{ Variables } & Frequencies $(\mathrm{n})$ & Percentage $(\%)$ \\
\hline Gender & 50 & 55 \\
Male & 40 & 45 \\
Female & & \\
Age & 6 & 6.7 \\
Less than 45 years & 84 & 93.3 \\
More than 45 years & & \\
Experience as Principal & 14 & 15.6 \\
Less than 1 year & 65 & 72.2 \\
2-10 years & 7 & 7.8 \\
11-20 years & 4 & 4.4 \\
More than 21 years & &
\end{tabular}

From the descriptive study, 50 (55\%) of the principals were males while $40(45 \%)$ were females. The majority of them, 84 (93.9\%) of the total, were more than 45 years of age, as compared to $6(6.7 \%)$ who were less than 45 years old. Furthermore, 65 (72.2\%) of the principals had 2 to 10 years of experience, followed by $14(15.6 \%)$ of them who had less than a year's experience, 7 (7.8\%) of them had 11-20 years' experience, and only 4 (4.4\%) of the principals had more than 21 years of experience. 
Measuring Principals' Technology Leadership level in terms of NETS-A standards

Table 1 shows the means and standard deviations for Principals' Technology Leadership and it constructs according to NETS-A. The mean score interpretation (moidunny, 2009) is as shown in Table 2.

Table 2

Mean Score Interpretation

\begin{tabular}{cc}
\hline Mean Score & Interpretation \\
\hline $1.00-1.80$ & Very Low \\
$1.81-2.60$ & Low \\
$2.61-3.20$ & Medium \\
$3.21-4.20$ & High \\
$4.21-5.00$ & Very High \\
\hline
\end{tabular}

Source: Moidunny (2009).

The findings revealed that technology leadership and all its five constructs show high category means in secondary schools around Kedah. The standard deviation of less than 1 , means that the variations in respondent's opinions were small. Technology leadership on the whole had a mean of $4.06(\mathrm{SD}=.46)$.

Table 3

Descriptive Statistics for Technology Leadership and Its Constructs

\begin{tabular}{cccc}
\hline Constructs & Mean & $\begin{array}{c}\text { Standard } \\
\text { Deviation }\end{array}$ & $\begin{array}{c}\text { Level of } \\
\text { Technology } \\
\text { Leadership }\end{array}$ \\
\hline Technology Leadership (Overall) & 4.06 & .46 & High \\
Visionary Leadership & 3.91 & .74 & High \\
Digital Age Learning Culture & 3.93 & .55 & High \\
Excellence in Professional Practice & 4.09 & .57 & High \\
Systemic Improvement & 4.18 & .46 & High \\
Digital Citizenship & 4.13 & .54 & High \\
\hline
\end{tabular}


The findings in Table 3 show that the Systemic Improvement construct had the highest mean $(\bar{X}=4.18, S D=.46)$, followed by Digital Citizenship $(\bar{X}=4.13, S D=.54)$, Excellence in Professional Practice $(\bar{X}=4.09, S D=.57)$, and Digital Age Learning Culture; the lowest was Visionary Leadership construct $(\bar{X}=3.91, S D=.74)_{\text {but }}$ it had the highest standard deviation (.74).

\section{Measuring Teachers' Technology Integration in Classrooms for Educational Purposes}

Table 4 shows the means and standard deviations for each item in the Learning with ICT: Measuring ICT Use in the Curriculum Instrument. Based on Moidunny's (2009) score interpretation, teachers in this study use ICT at a high level for all purposes.

Table 4

Descriptive Statistics for Teacher's Technology Integration Items

\begin{tabular}{|c|c|c|c|}
\hline Item & $\begin{array}{l}\text { I use ICT in the classroom so that my students } \\
\text { are able to: }\end{array}$ & Mean & SD \\
\hline 1 & acquire knowledge of the 21 st century & 3.28 & 1.04 \\
\hline 20 & $\begin{array}{l}\text { understand and be involved in the ever-chang- } \\
\text { ing knowledge economy }\end{array}$ & 3.32 & .99 \\
\hline 17 & $\begin{array}{l}\text { asses their own and the community's values } \\
\text { critically }\end{array}$ & 3.40 & .95 \\
\hline 10 & $\begin{array}{l}\text { integrate various media to create suitable } \\
\text { products }\end{array}$ & 3.42 & .94 \\
\hline 7 & develop scientific understanding of the world & 3.47 & .93 \\
\hline 18 & communicate with others locally and globally & 3.48 & .92 \\
\hline 5 & $\begin{array}{l}\text { build knowledge through curriculum integra- } \\
\text { tion }\end{array}$ & 3.49 & .94 \\
\hline 2 & become skilled in the subject they are studying & 3.50 & .95 \\
\hline 16 & improve inter-cultural understanding & 3.52 & .98 \\
\hline 3 & synthesise their knowledge & 3.52 & .91 \\
\hline 13 & implement the knowledge they have gained & 3.53 & .95 \\
\hline 9 & plan and manage curricular projects & 3.53 & .96 \\
\hline
\end{tabular}




\begin{tabular}{clcc}
\hline Item & $\begin{array}{l}\text { I use ICT in the classroom so that my students } \\
\text { are able to: }\end{array}$ & Mean & SD \\
\hline $19 \quad \begin{array}{l}\text { involve in independent learning through access } \\
\text { according to their own pace, time, and place }\end{array}$ & 3.56 & .88 \\
$4 \quad \begin{array}{l}\text { construct their own knowledge by collaborat- } \\
\text { ing with others }\end{array}$ & 3.57 & .97 \\
$11 \quad \quad \begin{array}{l}\text { involve continuously in curricular activities } \\
15\end{array} \quad \begin{array}{l}\text { be aware about the implications of ICT- based } \\
\text { global technology towards society }\end{array}$ & 3.60 & .94 \\
$14 \quad \begin{array}{l}\text { undergo formative and/or summative assess- } \\
\text { ments }\end{array}$ & 3.63 & .95 \\
6 & $\begin{array}{l}\text { develop in depth understanding about topics } \\
\text { studied }\end{array}$ & 3.64 & .83 \\
8 & $\begin{array}{l}\text { are motivated to carry out curricular tasks } \\
12\end{array} \quad$ support their learning process & 3.65 & .90 \\
\hline
\end{tabular}

Means and standard deviations were divided into three categories. The items $1,20,17,10,7,18,5$, and 2 had mean values from $\bar{X} 3.28$ to 3.50 , the items $16,3,13,9,19$, and 4 had mean values from $\bar{X}=$ 3.52 to 3.57 , and items $11,15,14,6,8$, and 12 had mean values from $\bar{X}=3.60$ to 3.74 . The highest standard deviation was for item $1(\mathrm{SD}=1.04)$ and lowest was for item $6(\mathrm{SD}=.83)$.

\section{Measuring the Relationship between Principal's Technology Leadership Level and Teachers' Technology Integration for Educational Purposes}

\section{Regression Analysis}

A simple linear regression analysis was conducted to examine the relationship between Technology Leadership level of principals and Teacher's Technology Integration. The null hypothesis was that the regression coefficient was equal to zero. Simple linear regression assumptions for linearity, normality, independence, and homogeneity of variance were tested and met. Table 5 shows that the technology leadership level measured in the PTLA score of principals were found to be a good predictor of teacher's technology integration, $F(1$, $88)=9.64, p=0.03, \mathrm{R}^{2}=.0 .10$. Principal's Technology Leadership behaviour accounted for 0.10 of explained variability of Teacher's Technology Integration in the classroom. 
Table 5

ANOVA for the Regression Equation, Principals' Technology Leadership on Teachers' Technology Integration

ANOVA $^{\mathrm{a}}$

\begin{tabular}{|c|c|c|c|c|c|c|}
\hline \multirow[t]{2}{*}{ Model } & & \multirow{2}{*}{$\begin{array}{l}\text { Sum of } \\
\text { Squares }\end{array}$} & \multicolumn{3}{|c|}{ Mean } & \multirow[b]{2}{*}{ Sig. } \\
\hline & & & df & Square & $\mathrm{F}$ & \\
\hline \multirow{3}{*}{1} & Regression & 286691.035 & 1 & 286691.035 & 9.638 & $.003^{\mathrm{b}}$ \\
\hline & Residual & 2617524.920 & 88 & 29744.601 & & \\
\hline & Total & 2904215.956 & 89 & & & \\
\hline
\end{tabular}

a. Dependent Variable: TTI

b. b. Predictors: (Constant), PTL

Table 6 shows the analysis of correlation which confirms the accuracy of the model. In this finding, $R=0.31$, which indicated a moderate correlation, and $R^{2}=0.10$, which meant the independent variable PTLA can explain $10 \%$ of the variability of the dependent variable (Teacher's Technology Integration). The Adjusted $R^{2}$ is also an estimate of the effect size, which is $8.8 \%$, indicative of a medium effect size, according to classification by Cohen (1988).

Table 6

Model Summary

Model Summary ${ }^{\mathrm{b}}$

\begin{tabular}{lrrrrr}
\hline Model & $\mathrm{R}$ & R Square & $\begin{array}{c}\text { Adjusted R } \\
\text { Square }\end{array}$ & $\begin{array}{l}\text { Std. Error of } \\
\text { the Estimate }\end{array}$ & Durbin-Watson \\
\hline $.314^{\mathrm{a}}$ & .099 & .088 & 172.46623 & .359 \\
\hline
\end{tabular}

Table 7 shows the regression equation for predicting the relationship between Principals' Technology Leadership and Teachers' Technology Integration, which is as follows: 
Teachers' Technology Integration $($ TTI $)=-79.558+8.203($ PTLA $)$

The equation predicts that one unit change in Principal's Technology Leadership score would increase the level of Teacher's Technology Integration in the classroom by 8.20 , with $\mathrm{p}=.003<0.05$, thus the relationship between PTLA and TTI is significant.

Table 7

Parameter estimates (Coefficients) ${ }^{a}$

Coefficients $^{\mathrm{a}}$

\begin{tabular}{|c|c|c|c|c|c|c|}
\hline \multirow[t]{2}{*}{ Model } & & \multicolumn{2}{|c|}{$\begin{array}{l}\text { Unstandardised } \\
\text { Coefficients }\end{array}$} & \multirow{2}{*}{$\begin{array}{c}\begin{array}{c}\text { Standardised } \\
\text { Coefficients }\end{array} \\
\text { Beta }\end{array}$} & \multirow[t]{2}{*}{$\mathrm{t}$} & \multirow[t]{2}{*}{ Sig. } \\
\hline & & B & Std. Error & & & \\
\hline \multirow{2}{*}{1} & (Constant) & -79.558 & 189.300 & & -.420 & .675 \\
\hline & PTL & 8.203 & 2.642 & .314 & 3.105 & .003 \\
\hline
\end{tabular}

a. Dependent Variable: TTI

The Effect of Professional Development as a Moderator on the Relationship between Principal' Technology Leadership Level and Teachers' Technology Integration for Educational Purpose

\section{Moderating Effect}

The researcher conducted the PROCESS procedure for SPSS, (Hayes, 2012) to identify the effect of the moderator between Teacher's Technology Integration and Principal's Technology Leadership. The screen capture shows that $F(3,86)=4.94, p=.0032, R^{2}=.1472$. Results of the ANOVA are shown in Figure 2.

From Figure 2, the regression equation for predicting the relationship between Principal's Technology Leadership and Teacher's Technology Integration is as follows: $F(3,86)=4.94, p<.005(.0032)$, $R^{2}=.15$. 


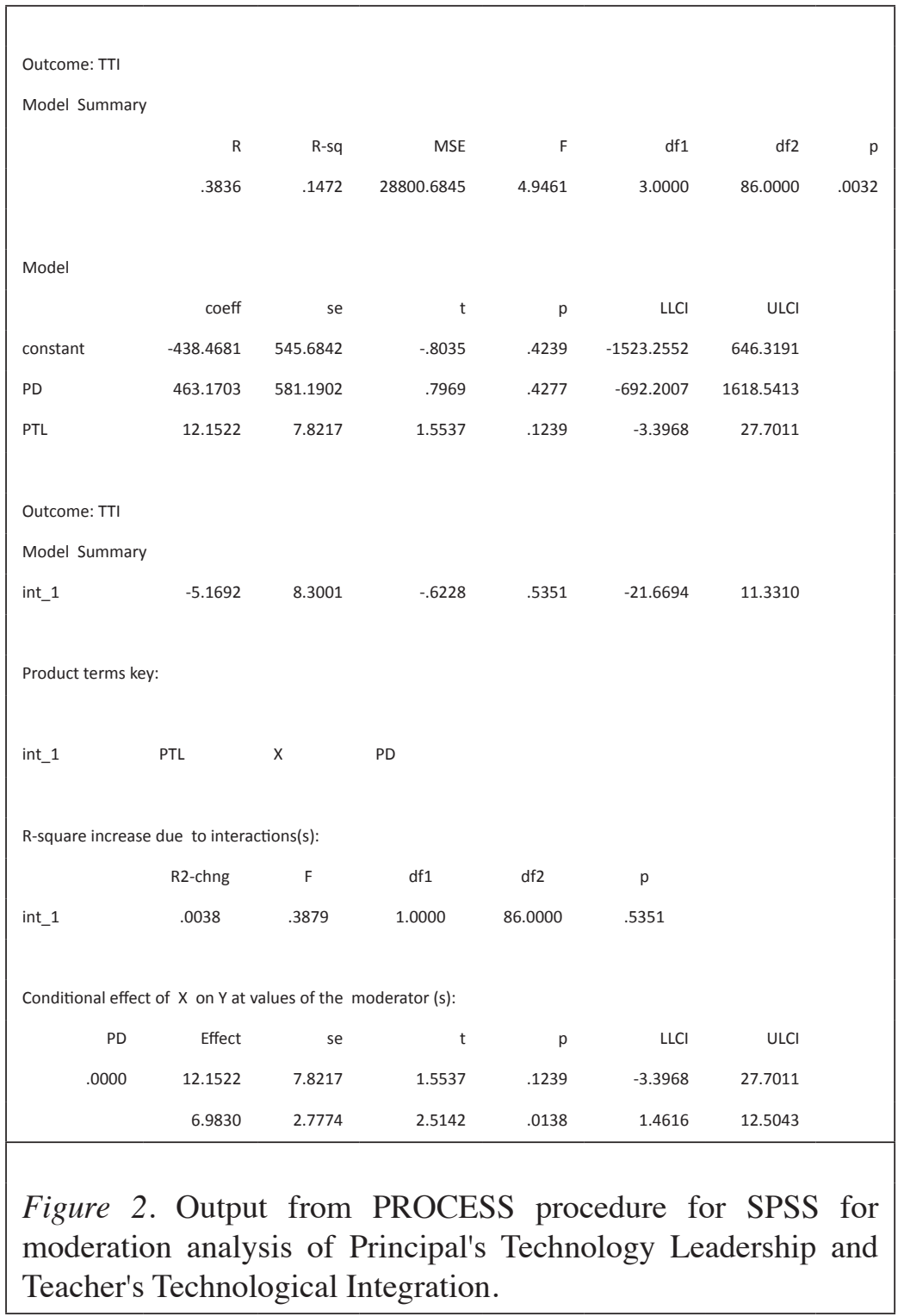

Note: PD=Professional Development, $.0000=$ Carried out by principals, $1.000=\mathrm{PD}$ not carried out by principals

$$
\text { TTI }=\text { - 438.47+12.15(PTL })+463.17(P D)-5.17(P T L * P D)
$$

The model summary shows that when professional development is not carried out by the principals, the effect of it as a moderator is 
not significant in the relationship between Principal's Technology Leadership and Teacher's Technological Integration, $t(86)=1.55$, $p>0.05$. When professional development is carried out by the principals, the effect of it as a moderator is significant in the relationship, where $t(86)=2.51, p<0.05$. Therefore, we can conclude that Professional Development moderated the relationship between Principals' Technology Leadership and Teachers' Technological Integration.

\section{DISCUSSION}

Overall this study indicates that the level of technology leadership amongst the Kedah secondary school principals is at a high level. This is consistent with Leong, Chua and Sathiamoorthy (2016); Alkrdem (2014); Fisher and Waller (2013), and Hamzah, Juraime, and Mansor (2016). Specifically, the principals in this study practised Systemic Improvement which has the highest mean of 4.18 compared to the other four constructs of NETS-A (2009).

This finding is in line with Hamzah et al. (2016) and Gencer and Samur (2016). The lowest mean was the Visionary Leadership construct, consistent with a study by Gencer and Samur (2016). This finding also supports the study conducted by Metcalf (2010) which showed that principals were least prepared for Visionary Leadership.

This study also found that technology was integrated at a high level (Moidunny, 2009). This is in agreement with Al-Jaraideh (2009), who investigated Jordanian schools where technology is highly integrated in the classrooms.

Findings were also in agreement with Hew and Tan (2016) who found that students involved in the PISA 2012, whose teachers explicitly used IT in the classroom, reported high levels of ICT integration. The results were consistent with studies done by Almekhlaji and Almequdadi (2010), who found that teachers integrated technology in their class activities in the United Arab Emirates.

This study found that Principals' Technology Leadership is a good predictor for Teachers' Technology Integration. This is similar to 
Tan (2010), and Fisher and Waller (2013) who found a correlation between Principals' Technology Leadership and Teachers' Technology Integration in the classroom.

The study showed that with Professional Development as a moderator, the relationship between Principals' Technology Leadership and Teachers' Technology Integration for educational purposes was significant. This finding implies that Professional Development is the deciding factor to facilitate technology integration in the classroom. As a result, we can conclude that a principal's support or ability in conducting professional development in schools indirectly helps facilitate or enhance the integration of technology in the classroom by teachers. Therefore, the Ministry of Education should consider professional development as one of the key constructs to measure ICT competency level of principals in Malaysia. This finding is in line with Grey-Bowen (2010), who proved that significant Professional Development needs were found for all constructs of the NETS-A, and Bredeson (2000) who supported the role of principals in the Professional Development of teachers. Studies by Bizzell (2011) showed that the principals needed training in the use of ICT for educational purposes.

Implications to Policy: Under the Malaysia Education Blueprint (MOE, 2013), continuous professional development have been designed for teachers and principals. The findings of this study support these government initiatives and suggests that further research needs to be done on planning effective technology leadership and ICT -infused training programmes for school principals to enable them to be essentially more efficient school leaders.

Implications to Principals: School principals must excel in professional practice and thrive to stay abreast with emerging trends of technology. Principals must become visionary leaders and promote an environment that empowers educators to enhance student learning through digital resources (Anderson \& Dexter, 2000, 2005, ISTE, 2014).

Implications to Theory: This study supports and contributes to the Anderson and Dexter $(2000,2005)$ model which proposes that school principals are the predictors of technological competency and have a direct impact on the technological outcomes in schools. The findings also are consistent with ISTE (2014) and meet the standards set for school principals to support technology integration in schools. 
Implications to Teachers: Technology must be integrated in the classroom according to 21 st century education and the needs of students of the $\mathrm{Z}$ generation who are digital natives. Professional development for principals must be designed so that they can become essential role- models and supervise teachers' technology integration.

This study was only carried out in the state of Kedah, and further research must be done in other states around Malaysia. As this was a quantitative study, it is suggested that future researchers design a mixed-methodology approach to obtain more concrete findings on the relationship between Principals' Technology Leadership and Teachers' Technology Integration and the effect of Professional Development as a moderator. This was a cross-sectional study and data was collected within a span of two months. It is recommended that a longitudinal study be carried out for more comprehensive findings.

\section{CONCLUSION}

This study has discovered a significant relationship between Principals' Technology Leadership and Teachers' Technology Integration in the classroom, and a significant effect of Professional Development as a moderating factor between Technology Leadership and Technology Integration in the selected national secondary schools in Kedah.

According to Papa (2011), it is the school principals' responsibility to become dynamic technology leaders who are crucial as the driving force for technology integration to be successfully implemented in schools. This can only be achieved through pragmatic and appropriate professional development for school principals (Byrom \& Bingham, 2001).

In tandem with the Second Wave of the Malaysia Blueprint for Education 2013-2025 (MOE, 2013) and the Industrial Revolution 4.0 , the findings of this study suggest that principals who transform to inspire teachers to integrate technology will be able to promote a generation of divergent thinking students, escalate student creativity and help produce skilled workforce for the 21 st century. 


\section{REFERENCES}

Albion, P. (2006). Technology leadership. Proceedings of the 17th International Conference of the Society for Information Technology \& Teacher Education (SITE, 2006). Orlando, FL.

Al-Jaraideh Yousef Ahmad. (2009). Factors affecting Information and Communication Technology (ICT) integration in Jordanian Secondary Schools (Unpublished doctoral dissertation), Universiti Utara Malaysia.

Alkrdem, M. (2014). Technological leadership behaviour of high school head teachers in Asir Region, Saudi Arabia. Journal of International Education Research (JIER), 10(2), 95-100 http://dx.doi.org/10.19030/jier.v10i2.8510

Almekhlaji, A. G., Almequdadi, F.A. (2010). Teachers' perception of technology integration in the United Arab Emirates school classrooms. Educational Technology and Society, 13(1), 165-175.

Anderson, R., \& Dexter, S. (2005). School technology leadership: An empirical investigation of prevalence and effect. Educational Administration Quarterly, 41(1), 49-82.

Anderson, R.E., \& Dexter, S.L. (2000). School technologyleadership: Incidence and impact (Teaching, Learning, and Computing: 1998 National Survey, Rep. NO.6). UC Irvine, Centre for Research on Information Technology and Organizations.

Badri, M., Alnuaimi, A., Mohaidat, J., Yang, G., \& Al Rashedi, A. (2016). Perception of teachers professional development needs, impacts, and barriers: The Abu Dhabi case. SAGE Open, 6(3). http://dx.doi.org/10.1177/2158244016662901.

Billheimer, Dixie M. (2007). A study of West Virginia principals : Technology standards, professional development, and effective instructional technology leaders. Theses, Dissertations and Capstones. Paper 55.

Bizzell, B. E. (2011). Professional development of school principals in the rural Appalachian region of Virginia (Unpublished doctoral dissertation), Virginia Polytechnic Institute and State University.

Bredeson,P.(2000). The school principal's role in teacher professional development. Journal of In-Service Education, 26(2), 385-401. http://dx.doi.org/10.1080/13674580000200114

Brislin R.W.(1970) Back-translation for cross-cultural research. Journal of Cross-Cultural Psychology, 1(3), 187-196. 
Byrom, E., \& Bingham, M. (2001). Factors influencing the effective use of technology for teaching and learning: Lessons learnt from the SEIR*TEC intensive site schools (2nd ed.). Greensboro, NC: University of North Carolina.

Chang, I. H. (2012). The effect of principals' technological leadership on teachers' technological literacy and teaching effectiveness in Taiwanese elementary schools. Educational Technology \& Society, 15(2), 328-340.

Chin, J. M. (2010). Theory and application of educational leadership. Taipei, TW: Wunan.

Cohen, J. (1988). Statistical power analysis for the behavioral sciences (2nd ed.). Hillsdale, NJ: Lawrence Earlbaum Associates.

Creswell, J. W. (2014). Educational research: Planning, conducting, and evaluating quantitative and qualitative research (4th ed.). Harlow, UK: Pearson. Dede.

Davies, P. M. (2010). On school educational technology leadership. Management in Education, 24(2), 55-61. doi:10.1177/0892020610363089

Dexter, S. (2008). Leadership for IT in schools. In Voogt, J., \& Knezek, G. (Eds), International handbook of information technology in primary and secondary education (pp. 541554). Springer: New York, NY.

Dexter, S. (2011). School technology leadership: Artifacts in systems of practice. Journal of School Leadership, 21(2), 166-189.

Dunham, C. (2012). Principals roles and responsibilities in technology integration in rural Georgia. Electronic Theses \& Dissertations. Paper 786.

Evers, A., Van der Heijden, B., \& Kreijns, K. (2016). Organisational and task factors influencing teachers' professional development at work. European Journal of Training and Development, 40(1), 36-55. http://dx.doi.org/10.1108/ejtd03-2015-0023.

Fisher, D. M., \& Waller, L. R. (2013). The 21st century principal: A study of technology leadership and technology integration in Texas K-12 schools. The Global E Learning Journal, 2(4), $1-44$.

Fullan, M. (2001). Leading in a culture of change. San Francisco, CA: Jossey-Bass.

Gençer, M. S. \& Samur, Y.(2016). Leadership styles and technology: Leadership competency level of educational leaders. ProcediaSocial and Behavioral Sciences, 229, 226-233. 
Greaves, T, H., Wilson, J. L., Gielniak, M. P., R. (2010). The technology factor: Nine keys to student achievement and costeffectiveness. Retrieved from https://www.k12blueprint.com/ sites/default/files/Project-RED-Technology-Factor.

Grey-Bowen, J. E. (2010). A study of technology leadership among elementary public school principals in Miami-Dade county. ProQuest LLC. 789 East Eisenhower Parkway, PO Box 1346, Ann Arbor, MI 48106.

Grissom, J.A., \& Harrington, J. R. (2010). Investing in administrator efficacy: An examination of professional development as a tool for enhancing principal effectiveness. American Journal of Education, 116(4), 583-612.

Guskey, T.R., \& Sparks, D. (1996). Exploring the relationship between staff development and improvements in student learning. Journal of Staff Development, 17(4), 34-38.

Hamzah, M., Juraime, F., Hamid, A., Nordin, N., \& Attan, N. (2014). Technology leadership and its relationship with School-Malaysia standard of education quality (SchoolMSEQ). International Education Studies, 7(13), 278-285. http://dx.doi.org/10.5539/ies.v7n13p278

Hamzah, M., Nordin, N., Jusoff, K., Karim, R., \& Yusof, Y. (2017). A Quantitative analysis of Malaysian secondary school technology leadership. Dx.doi.org. Retrieved from http://dx.doi.org/10.3968/j.mse.1913035X20100402.012

Hayes, A. F. (2012). PROCESS: A versatile computational tool for observed variable mediation, moderation, and conditional process modelling [White paper]. Retrieved from http://www. afhayes.com/ public/process2012.pdf

Hew, K. F., \& Tan, C.Y. (2016). Predictors of information technology integration in secondary schools: Evidence from a large scale study of more than 30,000 students. PLOS ONE, 11(12): e0168547. https://doi.org/10.1371/journal.pone.0168547

International Society for Technology In Education (ISTE) (2000). National Educational Technology Standards (NETS) for teachers. Retrieved from http://cnets.iste.org/teachers/

International Society for Technology in Education. (2002). National Education Technology Standards Project. Retrieved from http://cnets.iste.org/credits html

International Society for Technology in Education. (2009). National Education Technology Standards for Administrators. Retrieved from http://www.iste.org/ docs/pdfs/nets-a-standards.pdf 
International Society for Technology in Education (ISTE). (2014, July 1). ISTE standards administrators. Retrieved from http:// www.iste.org/standards

Jamieson-Proctor, R., Watson, G., \& Finger, G. (2003). Information and communicationtechnologies(ICTs) curriculumintegration performance measurement. Report on the development of an ICT curriculum integration performance measurement instrument. Brisbane, Australia: Griffith University.

Jamieson-Proctor, R., Watson, G., Finger, G., \& Grimbeek, P.M. (2005). An external evaluation of Education Queensland's ICT Curriculum Integration Performance Measurement Instrument. Brisbane, Qld: Griffith University.

Jamieson-Proctor, R., Finger, G., \& Albion, P. (2010). Auditing the TPACK capabilities of final year teacher education students: Are they ready for the 21 st century? In Proceedings of the 2010 Australian Computers in Education Conference (ACEC 2010) (pp. 1-12). Australian Council for Computers in Education.

Johnson, P. O., \& Neyman, J. (1936). Tests of certain linear hypotheses and their applications to some educational problems. Statistical Research Memoirs, 1, 57-93.

Johnston, M., \& Cooley, N. (2001). What we know about: Supporting new models of teaching and learning through technology. Arlington, VA: Educational Research Service.

Krejcie, R.V., \& Morgan,D.W.(1970). Determining size for research activities. Educational and Psychological Measurement, 30, 607-610.

Kurland, H., Peretz, H., \& Hertz-Lazarowitz, R. (2010). Leadership style and organizational learning: The mediate effect of school vision. Journal of Educational Administration, 48(1), 7-30. http://dx.doi.org/10.1108/09578231011015395

Latham, B. (2007). Sampling: What is it? Retrieved from www. webpages.acs.ttu.edu/riatham/.../Sampling_Methodology_ Paper.pdf

Leong, M., Chua, Y., \& Sathiamoorthy, K. (2016). Relationship between principal technology leadership practices and teacher ICT competency. Malaysian Online Journal of Educational Management, 4(3), 13-36. Retrieved from https://mjes. um.edu.my/index.php/MOJEM/article/view/6062

Machado, L. J., \& Chung, C. J. (2015). Integrating technology: The Principals' role and effect. International Education Studies, 8(5), 43-53. 
MacNealy, M. S. (1999). Strategies for empirical research and writing. Boston: Allyn \& Bacon.

Metcalf, W. B. (2012). K-12 principals' perceptions of their technology leadership preparedness (Unpublished doctoral dissertation), Georgia Southern University. Retrived from https://digitalcommons.georgiasouthern.edu/cgi/view content.cgi? article $=1400 \&$ context $=$ etd

Michael, S. (1998). Best practices in information technology (IT) management: Insights from K-12 schools' technology audits. International Journal of Educational Management, 12(6), 277-288.

Ministry of Education. (2013). Malaysia Education Blueprint 20132025. Putrajaya. KPM.

Ministry of Education. (2012). Malaysia Education Blueprint 20132025. Putrajaya. KPM.

Moidunny, K. (2009). The effectiveness of the National Professional Qualifications ForEducationalLeaders (NPQEL)(Unpublished doctoral dissertation), Bangi: The National University of Malaysia.

Noraini Idris. (2013). Penyelidikan dalam pendidikan (2nd ed). Kuala Lumpur: Mc Graw-Hill.

Nunnally, J.C. (1978). Psychometric theory (2nd ed). New York: McGraw-Hill.

Papa, R. (2011). Technology leadership for school improvement. Thousand Oaks: Sage Publications.

Peled, Y., Kali, Y., \& Dori, Y. (2011). School principals' influence on science teachers' technology implementation: A retrospective analysis. International Journal of Leadership in Education, 14(2), 229-245. Retrieved from http://dx.doi.org/10.1080/136 03124.2010 .524249

Richardson, J. W. \& McLeod, S. (2011). Technology leadership in Native American schools. Journal of Research in Rural Education, 26 (7), 1-14.

Richardson, J., Bathon, J., Flora, K., \& Lewis, W. (2012). NETS•A Scholarship.Journal of Research on Technology In Education, 45(2),131-151. http://dx.doi.org/10.1080/1539152 3.2012 .10782600

Roblyer, M., \& Doering,A. (2014). Integrating educational technology into teaching. Harlow: Pearson.

Senge, P. M. (1990). The fifth discipline. The art and practice of the learning organization. London, England: Random House. 
Sincar, M. (2013). Challenges school principals facing in the context of technology leadership. Educational Sciences: Theory \& Practice, 13(2), 1273-1284.

Tan, S.C. (2010). School technology leadership: Lessons from empirical research. In C. H. Steel, M. J. Keppell, P. Gerbic \& S. Housego (Eds.), Curriculum, technology \& transformation for an unknown future. Proceedings Ascilite Sydney 2010 (pp.896906). http://ascilite.org.au/conferences/sydney10/procs/Sengchee-tan-full.pdf

U.S.Department of Education, National Centre forEducation Statistics. (2005). The Condition of Education 2005 (NCES 2005-094). Washington, DC: U.S. Government Printing Office.

Wang, C. (2010). Technology leadership among school principals: A technology-coordinator's perspective. Asian Social Science, $6(1), 51-54$. 